\title{
ISLAMIC RELIGIOUS LEARNING FOR MUALLAF AT PESANTREN
}

\section{Hariman Surya Siregar}

UIN Sunan Gunung Djati Bandung

Jl. A. H. Nasution No. 105, Bandung, Indonesia, 40614

Email: harimansuryasiregar@uinsgd.ac.id

\section{Mohd Roslan Mohd Nor}

Academy of Islamic Studies, University of Malaya, Malaysia

0603 Kuala Lumpur, Selangor, Malaysia

Email: m_roslan@um.edu.my

\section{Hajrullah}

Universitas Islam Ar-Raniry Banda Aceh

Jl. Syech Abdul Rauf, Banda Aceh, Aceh, Indonesia, 23111

Email: hazrullah@gmail.com

Received: 09, 2020. Accepted: 12, 2020. Published: 12, 2020

\begin{abstract}
This study aims to describe the learning activities of Islamic Religious Education at the An-Naba Islamic Boarding School for muallaf. This research used a qualitative approach with a descriptive analytic method. Interviews, observation and documentation were applied to collect the data. Data were analyzed using the Milles and Huberman model analysis. The results showed that learning Islam for muallaf has the objectives to improve the quality of learning, create an ideal Muslim personality, foster Muslim morals, Muslim salimah personalities, and Muslims as caliphs. The optimization program for Islamic religious learning consists of a coaching program, an educational program, a development program, and a vocational education development program. The process of organizing Islamic religious learning for muallaf consists of four stages: shabâdah (the process of Islamization); ta'âruf (introduction) and tafâhum (understanding); ibthan (internalization); and muwâfaqah (acceptance).
\end{abstract}

Keywords: Islamic Education, Muallaf, Optimization Program, Religious Conversion

\begin{abstract}
ABSTRAK
Penelitian ini bertujuan mendeskripsikan kegiatan pembelajaran Pendidikan Agama Islam di Pesantren An-Naba bagi muallaf. Penelitian ini menggunakan pendekatan kualitatif dengan metode deskriptif analitik. Pengumpulan data dilakukan melalui wawancara, observasi, dan dokumentasi. Analisis data menggunakan analisis model Milles dan Huberman. Hasil penelitian menunjukkan, pembelajaran Pendidikan Agama Islam bagi muallaf bertujuan meningkatkan kualitas pembelajaran, mewujudkan kepribadian muslim yang ideal, menumbubkan akblak muslim, kepribadian muslim salimah, dan muslim sebagai khalifah. Program optimalisasi pembelajaran agama Islam terdiri dari program pembinaan, program pendidikan, program pengembangan, dan program pengembangan pendidikan vokasi. Proses penyelenggaraan pembelajaran Pendidikan Agama Islam bagi muallaf terdiri dari empat tahap: shahadah (proses islamisasi); ta'aruf (pengenalan) dan tafahum (pemahaman); ibthan (internalisasi); dan muwâfaqah (penerimaan).
\end{abstract}

Kata Kunci: Konversi Agama, Muallaf, Optimalisasi Program, Pembelajaran Pendidikan Agama Islam 


\section{INTRODUCTION}

Religion, to borrow the term from anthropologists is a universal phenomenon found in every society. In line with this, Henri Bergson's stated that there has never been a society with local religions. In particular, Raymonth Firth's expressed that religion is universal in human societies (Hadidjah \& Karman, 2010). Humans as homo religious is a reality. This statement confirms that humans have a natural disposition in choosing their beliefs, including when someone chooses to become a convert. Convert refers to someone who transforms his belief from one religion to another (Maraghi, 2000; McGuire, 2002; Rahman et al., 2019). In Islamic term, this individual conversion to new religion is called muallaf (converts).

Islam is a universal religion. This religion has been followed by millions people all around the world. It is open to all regardless people color, tribe and other cultural aspects. Anyone can adhere to the religion. Therefore it is the responsibility of every Muslim whether an individual, community or government and non-governmental organization to convey the teachings of Islam to non-Muslims. The guiding efforts should be provided to these groups after their religious conversion to Islam. They are known as the muallaf .

Tumanggor (2016), Buxant. et al. (2009), Chauhan (2017), described that converting to Islam is a form of religious conversion related to accepting this new religion based on needs and aspirations. According to the researches, one of these needs and aspirations is influenced by social conditions (religious realities) (James, 1967; Boz, 2011; Harun, et. al., 2012). Furthermore, Hakim (2019) and Yudha \& Setiyowati (2016) stated that there are factors behind a person's religious conversion, including marriage, psychological conflicts, selfawareness, and self-will. Hardi (2019) and Kurnia \& Sani (2018) showed that the conversion of Chinese ethnic religions or beliefs to Islam or Christianity is generally caused by marriage with indigenous tribes. According to Noviza (2015), religious conversion among congregations of the Muhammad Cheng Ho Mosque in Palembang is due to psychological and social factors. Other contributing factors include the influence of interpersonal relationships and the influence of advice from friends or families, liberation from inner pressure, loneliness, and lack of recognition from friends and families (Noviza, 2015).

In the context of religious conversion, when a person has officially experienced a new nuance in belief, he is required to be able to know the values of a new religious system, to behave according to the new system, to be able to adjust and carry out activities according to the new religion. Ideally, religious conversion requires a person's life to change because changing religions is a fundamental change and arrangement of one's identity, meaning of life, and activities (Abdillah \& Sjafei, 2019; Kilbourne, \& James, 1989; Zinnbauer \& Kenneth, 2015). When a person is converted, he or she learns to adapt to many things about the new religious system. Research conducted by Emang, (2014) on Chinese religious conversion in Bengkulu, they reported that persons converting to Islam require circumcision, abstinence from eating prohibited foods, such as pork, abstinence from drinking alcohol, prostitution, lying, and gambling.

A number of muallaf admitted that before their religious conversion experience, they were confused about finding people or institutions that could help them answer religious problems. They have problems in carrying out Islamic teachings, especially the pillars of Islam. The problems include feeling lazy to perform praying and fasting Ramadan, lacking awareness of converts, feeling doubt in carrying out obligations, taking time to carry out their obligations, and looking for conformity in deepening Islamic teachings (Supriadi, 2018; Gepu, 2018). Responding to the problems encountered by converts to Islam, the Ministry of Religion of the Republic of Indonesia in 2009 held a forum of discussion, which took place at the Tryas Hotel Cirebon. In that discussion forum, converting people to Islam have expressed that they did religious conversion because they must meet the requirements to marry a Muslim 
woman. One of the convert participants expressed the existence of converts who returned to their previous beliefs (murtad). There is a stereotypical view of converts who return to their previous religion. They have converted to Islam just to play with Islamic creeds (Muljana, 2011).

There are many reasons why muallaf return to their previous religion. Apart from the stereotypical view of converts about their religious conversion, it is necessary to look for the factors that cause their faith to waver so that they return to their previous religion. This phenomenon has something to do with the findings reported by Noviza, (2015). The factors include interpersonal relationships, advice from closest people, liberation from inner pressure, loneliness, and lack of recognition can be used as references. Efforts to provide the understanding and deepening of how to worship, behave and build communication between humans as social beings to converts need to be carried out continuously and in a structured manner so that muallaf can increase their faith, devotion, and belief that Islam as their religion can solve their problems. Someone who chooses a religion that Allah loves needs to be followed up by optimizing Islamic religious education learning.

There is a huge number of muallaf in Indonesia. According to Widodo (2017), the number of muallaf in Indonesia has reached 10,000. Referring to these data, educational institutions such as Islamic boarding schools for converts have great opportunities to develop Islam in Indonesia. Some places in Indonesia are dedicated to fostering converts to deepening the teachings of Islam, such as Basecamp Meratus in South Kalimantan, Islamic guidance for Dayaks in Kalimantan, training for converts in the Sidraf area, training for converts in Negeri Sembilan, Malaysia, Attaibin Islamic Boarding School, Cibinong, Bogor, and others.

Muallaf, who study Islam in these institutions, often experience doubts in implementing Islamic teachings. Meanwhile, human challenges are generally dominated by individual internal challenges. For example, the nature of a happy person with what is already there and the drive of curiosity, which Ramayulis, (2009) calls curiosity. Guiding muallaf was done through the establishment of Cheng Hoo Mosque throughout Indonesia. This effort is seen as as part of social responsibility and mutual care among Chinese and other non-Chinese Muslims. In the future, the prospects for the fostering of the ethnic Chinese Muslim community in Indonesia would certainly benefit from greater systematization and organizational management. This study also finds that advancements in information technology present opportunities, as well as challenges in the millennial era to spread the teaching of Islam (Mahfud, 2018).

Muallaf can be found in some countries whose majority religion is not Islam like South Korea. In the country, muallaf has reached a very significant increase in the number of converts (Muallaf) statistical number. Muallaf in Kore is very high, but they are limited in Language. Worship facilities are also very rarely found to be used by muallaf. Learning media are generally presented and delivered in English. This makes most Korean people difficult to understand Islam because of language barrier. They need more sources delivered using Korean Language (Praditasari et.al, 2019).

Behind the curiosity, sometimes humans, including converts, have a mental attitude of doubt, so they need friends who can motivate them to uphold religion and live a normal life in the future. There are four main problems experienced by converts psychologically, namely changing religions, converting to religion, becoming converts, and self-change where changes occur not only in themselves but also in social interactions (Umam, 2014). In this context, Muslims' role is expected to provide motivation and confidence to converts around them in the form of Islamic religious learning activities. This support and motivation are needed to strengthen his new belief to cling to his religion.

Islamic religious education for muallaf needs to be well designed and implemented effectively and efficiently. This is aimed at providing converts the ease and joy of being a 
Muslim. There are several patterns of Islamic religious education carried out for converts. For example, Hakim (2013) reports on the pattern of fostering the Islamic religion in Sidrap, South Sulawesi, which accentuates the development of individual obligations. Hidayati (2014) reports research on coaching for converts in Singkawang, Kalimantan through guidance and counseling.

From an education perspective, a learning activity - according to some experts' views has several components, including objectives, teachers, students, curriculum, methods, and evaluation (Hawi, 2013; Mahfud, 2011). Likewise, learning Islamic religious education for converts also refers to these components. Muallaf educating institutions in Indonesia are active in nurturing and fostering students (converts) to have the best knowledge, abilities, behavior, and attitudes of Islam, both vertically (interacting with Allah) And horizontally (interacting with society and their environment through the process learn and practice regularly the pillars imân, islâm, and ihsân. The Islamic education institutions for converts have also offer learning programs for converts. One of them is Pesantren An-Naba, a foundation focusing on educating muallaf to Islam.

At a pesantren, as an institution that focuses on religious education, teaching and learning is the main activity in enhancing students' capacities. Pohl (2006) noted that although pesantren is a place for learning the Arabic language, there have always been difficulties in the process of teaching and learning. One of which is the limited facilities and medium for teaching, so limited that teachers are left with no choice other than to just deliver their lessons in the classrooms (Wekke \& Hamid, 2013).

Pesantren are Islamic educational institutions that share many common characteristics. Their physical and organisational structures commonly share several elements: mosque, dormitory, students (popularly called santri), and kiai (Islamic scholar who leads pesantren). The central place is occupied by a mosque where the students and kiai pray five times a day, and do other activities that involve a large number of people, such as public lectures, collective prayers, and public preaching. The house of the kiai is commonly located beside the mosque and the dormitory where the students reside. Today's pesantren alsocommonly have class rooms and other school buildings. The other characteristic is the teaching of Islamic texts, organised mainly after prayer times (Isbah, 2020).

Pesantren An-Naba serves as an institution that provides guidance on Islamic religious learning for muallaf. However, to date, scholarly research on the work of Pesantren An-Naba still very rare. There is a need to conduct a serious study on the institution. There are some questions that can be raised, whether An-Naba has the same program as other institutions that deal with the process of nurturing muallaf, what are the goals and orientation of the development of Islamic religious education at the foundation; how is the learning process; and how is the learning model used? The research on An-Naba is vital since this educational institution converts to the capital city with the various challenges they face. This has an impact on the learning programs offered to converts, including the methods and models used.

\section{METHOD}

The method used in this study is a qualitative approach. This approach aimed to uncover ideas and optimization of Islamic religious learning at the An-Naba Center Muslim community. To collect the data, observation, documentation, and interview were conducted. Triangulation was applied to ensure the credibility of the data. The data were then analyzed inductively since qualitative research results emphasize meaning more than generalization (Sugiyono, 2014).

This study applied the descriptive method. The researchers conducted interviews with the foundation's leaders, asatidz (teachers), and the converts (students) at the Lautze Mosque 
and Pesantren An-Naba. The observation was conducted for activities related to the optimization of Islamic learning and religious practices carried out and developed in the Lautze Mosque and at the Pesantren An-Naba.

This study obtained the primary data from Mudhirul Ma'bad Pesantren An-Naba, Ustad Arifin Nababan; Council of Teachers (Asatidzab) teaches at Pesantren An-Naba; the Chairperson (Fedius Ndru) and the teachers who teach at Pesantren An-Naba; and students or muallaf to Islam. Data analysis techniques used in this study are based on the concept of Milles and Huberman, an interactive model that classifies data analysis in three steps, namely: data reduction, data presentation, conclusions; (verification).

\section{RESULTS AND DISCUSSIONS}

Based on the objectives of the study, there are three findings to describe in this section. The first findings concern the objectives of Islamic religious learning for muallaf at Pesantren An-Naba. The second finding deals with the optimization of Islamic religious learning at Pesantren An-Naba. The last findings have something to do with the process of Islamic religious learning implementation for muallaf at Pesantren An-Naba.

\section{The Objectives of Islamic Religious Learning for Muallaf at Pesantren An-Naba}

This study found that Pesantren An-Naba had designed a learning program and taught various learning materials for muallaf students. The learning activity was carried out classically. This condition becomes exciting because An-Naba Centre belongs to non-formal education with the learning process carried out similar to formal education. This is to say that the institution applied the classical system. The process becomes fascinating because learning activities in the institution used learning guides based on a curriculum created and designed by the institution.

Based on the observation, this study found that Pesantren An-Naba has set the learning objectives. The purpose of Islamic education at Pesantren An-Naba is to realize a human being with a personality of Muslims both physically and mentally, to devote all his deeds to seeking the blessings of Allah, to nurture faith, and to broaden Islamic knowledge. Also, it seeks to explore mutual support to achieve the objective of Islamic religious learning at AnNaba can be realized.

Based on the observation, this study found that Pesantren An-Naba developed Islamic religious learning activities. It designed Islamic religious education learning activity combined with religious material and the effects of daily life behavior. It delivered this learning material in class with religious teachers. The teachers taught material based on their respective subjects. Even though the An-Naba center is included in the non-formal education category, it applied the classical system's learning process as applied to formal educational institutions. It has tried to optimize the Islamic religious learning for muallaf students.

Pesantren An-Naba has a reasonably broad distinction compared to other similar institutions. It educated converts with the system that enables the Islamic educational institution to provide reports on students' mastery of Islamic learning. It can measure and evaluate the student's mastery of the material they learned. The way An-Naba provides Islamic religious instruction is similar to a formal madrasah in providing learning patterns.

In an interview, the Pesantren An-Naba principal has stated that the objectives of Islamic religious learning at the pesantren are to improve the quality of learning; to nurture ideal Muslim personality; and develop Muslim personalities (Nababan, personal communication, July 20, 2018). An-Naba has set its learning objectives for muallaf. It empowers the muallaf students to understand the principles of what they learn in the class. The learning material and activity were provided and compatible with the objectives of Islamic 
religious learning at An-Naba. This educational practice is well managed and implemented to empower the muallaf to nurture Muslim personality and attitude (Kawangit et al., 2012).

From an education perspective, a learning activity - according to some experts' views has several components, including objectives, teachers, students, curriculum, methods, and evaluation (Hawi, 2013; Sutrisno \& Suyatno, 2015). The objectives of learning will to some extent establish and set the material and learning activity. Likewise, learning Islamic religious education for converts also refers to these components. The institution should have clear objective to serve Islamic religious educaiton for Muallaf

\section{The Optimization Program for Islamic Religious Learning for Muallaf}

An-Naba was established for a particular reason. According to the principal's interview, he stated that he had established the An-Naba center because he was concerned with muallaf. He used to meet muallaf, who were displaced and slept under the Istiqlal mosque in Jakarta. This condition was very alarming because after converting to Islam, some were driven out of their homes and lived almost without parents or families' protection. This steep road they chose because they believed they were sure Islam is very suitable in fulfilling the inner rumble of the truth of the teachings of Islam (Nababan, personal communication, July 20, 2018)

Muallaf has no easy choice to undergo in their new life. Based on the principal's statement concerning muallaf life, some information could be gathered. They may separate from their loving family. Some were intimidated by relatives, neighbors, and friends who were previously close to them. They were no longer considered part of the family, and even they faced terror threats. This severe condition was challenging for muallaf. Also, they had not developed a proper and secure faith. Some of them committed apostasy and returned to their previous religion. Given this situation, mic sources to empower their faith. We may raise questions: Why are they displaced? Why did they return to apostasy? Why are they left to suffer alone? (Nababan, personal communication, July 20, 2018)

Pesantren An-Naba has its vision to achieve the educational goal. Based on the observation, this study found data concerning the vision and mission. Pesantren An-Naba was established to meet the need of muallaf. It was aimed at assisting muallaf to deal with their fundamental problems. It managed to deliver learning activities to enable muallaf to participate and gain knowledge and practice Islamic teaching. Its main goal is to foster, educate, and support muallaf until they become noble human beings, preachers, and spread kindness to others. Muallaf were educated systemically based on the orientation to form a robust Islamic aqeedah. They equipped them with special skills to have abilities that can later be useful in social life for themselves and society and the community. Pesantren An-Naba has School Vision, stating: "Establishing a personal Muslim who is kaffah and can become an avant-guard (goalkeeper) for strengthening the Islamic Aqeedab."

Pesantren An-Naba explicitly designs its mission to achieve the vision of pesantren. According to an interview with the developing team, this study found data concerning the missions of pesantren. As a non-formal educational institution, Pesantren An-Naba develops Muslim individuals who are kaffah, own noble character, and independent spirit. Pesantren An-Naba has explicitly stated its missions as follows: replacing previous beliefs with Islamic faith; implanting a solid Islamic foundation based on the Qur'an and Sunnab; nurturing Da'i who are militant with Islamic insight; forming a Muslim person who has good morality, independent and skilled; promoting unity among young Indonesian Muslims in providing support to build their faith and piety. Based on pesantren An-Naba's missions, it can be viewed that the institution has an effort to develop Islamic education for muallaf. They have the potential and assets to build a faithful and devout nation society (Nababan, personal communication, July 20, 2018). 
Table 1. Programs for Muallaf Organized by Pesantren An-Naba

\begin{tabular}{|c|c|c|}
\hline Coaching Program & Education Programs & Development Program \\
\hline $\begin{array}{l}\text { 1. Providing the basics of } \\
\text { Islamic faith aqeedab through } \\
\text { regular studies } \\
\text { 2. Providing the basics of } \\
\text { comparative religion } \\
\text { 3. Providing sermon training } \\
\text { and or public lectures. }\end{array}$ & $\begin{array}{l}\text { 1. Organizing non-formal education } \\
\text { programs with pesantren pattern } \\
\text { 2. Aspiring to hold formal education } \\
\text { from elementary /MI to tertiary } \\
\text { institutions for the Muslim } \\
\text { community. }\end{array}$ & $\begin{array}{l}\text { 1. Memorizing the Quran and } \\
\text { its interpretation } \\
\text { 2. Memorizing the Hadith } \\
\text { and its surah } \\
\text { 3. Mastering Arabic Language } \\
\text { 4. Mastering English } \\
\text { Language } \\
\text { 5. Mastering Computer } \\
\text { 6. Developing Vocational } \\
\text { Education }\end{array}$ \\
\hline
\end{tabular}

Table 2. Work Programs for Muallaf Organized by Pesantren An-Naba

\begin{tabular}{|c|c|c|c|}
\hline ing Program & Education Programs & Development Program & Vocational Program \\
\hline $\begin{array}{l}\text { 1. Providing the basics } \\
\text { of Islamic Aqeedah } \\
\text { through routine } \\
\text { studies carried out } \\
\text { every Asr until } \\
\text { Magrib, continued } \\
\text { with tahfid al-Quran; } \\
\text { 2. Providing the basics } \\
\text { of Comparative } \\
\text { Religion } \\
\text { 3. Providing effective } \\
\text { sermon training and } \\
\text { lectures according to } \\
\text { current methods. } \\
\text { (Da'wah } \\
\text { management). }\end{array}$ & 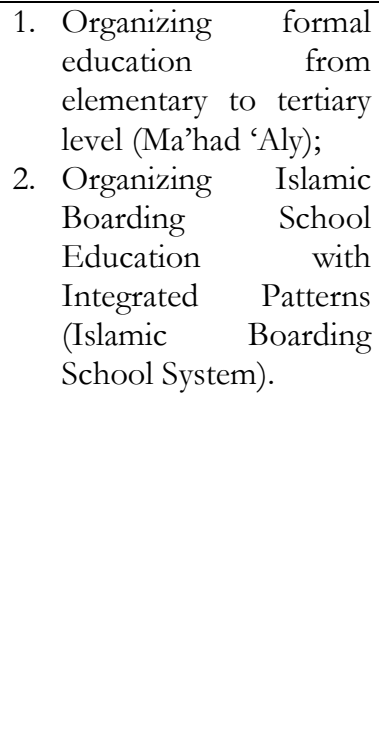 & $\begin{array}{l}\text { 1. Memorizing the } \\
\text { Quran and its } \\
\text { Interpretation; } \\
\text { 2. Memorizing Hadith } \\
\text { and Its History; } \\
\text { 3. Arabic proficiency; } \\
\text { 4. English proficiency }\end{array}$ & $\begin{array}{l}\text { 1. Organizing Vocational } \\
\text { Education } \\
\text { 2. Organizing Baitul Mal } \\
\text { wa Tamwil; } \\
\text { 3. Establishing } \\
\text { supermarket Anna } \\
\text { 4. Establishing Hajj and } \\
\text { Umrah Service Center; } \\
\text { 5. Organizing } \\
\text { Consultation center } \\
\text { for comparative } \\
\text { religion and Islamic } \\
\text { law; Sakinah } \\
\text { 6. Organizing Sansultation } \\
\text { Family Con } \\
\text { Center; } \\
\text { Establishing pesantren } \\
\text { Economic } \\
\text { Cooperative. }\end{array}$ \\
\hline
\end{tabular}

An-Naba has managed the program and work program to develop its institution for a better result and educational service. Optimization for an organization refers to the process of making the best thing from an organization's predetermined goal. Pesantren An-Naba can conduct optimization efforts. Its programs are in line with the objectives of Islamic education in various levels of education. The aim of Islamic education is ultimately in accordance with the goals of human life and its role as creatures created by Allah. The goal should be directed toward insân kâmil (Ramayulis, 2015).

Muallaf should be taught in pesantren with proper and well-designed curriculum. Given this situation, muallaf can meet their need to learn Islam. They can also fulfill their motives in converting to Islam (Hakim, 2019). Even though muallaf have been forced to convert to Islam prior to their marriage, they can learn more from the institution (Hardi, 2019; Kurnia \& Sani, 2018). In pesantren for muallaf, they may receive interpersonal relationships and the influence of advice from friends or families, to strengthen their religious conversion process (Noviza, 2015).

\section{The Process of Islamic Religious Learning for Muallaf}

a. Stages of Islamic Religious Learning

Based on the observation, this study found that Pesantren An-Naba with the asatidz had carried out various formulations, especially in various Islamic learning activities delivered to the muallaf. By doing so, Pesantren An-Naba expected that all muallaf who become 
permanent students do not feel confused after they converted from their previous religion to Islam. This study found that Pesantren An-Naba featured various formulations of Islamic religious learning activities for muallaf as follows:

1. Ta'aruf or Introduction to Islamic Teachings

Based on the interview with asatidz, they stated that prospective muallaf who come to the An-Naba Center typically had some goals. One of them is to express their desire to convert to Islam. Those who come to Pesantren An-Naba were not immediately accepted. They were asked several questions to explore their previous experience. They were asked to introduce themselves, their religious background before they convert to Islam, to explain the purpose of their plan to convert to Islam. Those are some of the questions raised by asatidz at Pesantren An-Naba Center. Also, the prospective students were accompanied by escorting people who were already Muslim. They usually talked about several things related to Islamic religious conversion (Asatidz, personal communication, July 19, 2018)

Taaruf activities, known as the introduction of prospective muallaf to Pesantren AnNaba, exploit them to explore their motivation and decision about Islam. In this process, the prospective muallaf and students at Pesantren An-Naba conducted discussions to familiarize participants with Islamic teachings. Taaruf process is done once, but it can be carried out several times until prospective muallaf who will become a student at An-Naba Center feels that he is convinced to embrace and study Islam.

In an interview, the official of Pesantren An-Naba explained the process of taaruf. The activities involve how prospective muallaf experience intensive discussion. They were introduced to questions before entering and studying Islam. They were given opportunities to deepen Islamic religious learning further before they converted to Islam with full confidence. After muallaf proceed this taaruf activity, they found that they had believed the wrong religion. They were allowed to embrace Islam. This process was intended to prepare muallaf to explain to his family that their religion was wrong when asked or argued. After the prospective muallaf believe that the religion held previously is wrong, the next stage is to convert to Islam with no coercion (Ali, personal communication, July 30, 2018).

Taaruf activity has several advantages for Pesantren An-Naba when it comes to knowing the motives of prospect muallaf. In an interview, Pesantren An-Naba's staff states: "unlike in other places, at Pesantren An-Naba, a prospective muallaf who came to convey their desire to embrace and study Islam was officially welcomed, but they were not announced in mosques or public space. At Pesantren An-Naba, prospective muallaf who came were questioned, interviewed. This is to avoid the impression that prospective muallaf plans to convert to Islam and are in a state of the indecisive situation. This was done because there was a bad experience of a prospective muallaf who converted to Islam at Pesantren An-Naba. He had uttered shabada at Pesantren An-Naba, and then he returned home. In his family, he was treated unfavorably, ostracized, and expelled from the house. Based on this experience, Pesantren An-Naba tries to avoid this bad experience for Muallaf by conducting taaruf. (Ali, personal communication, September 30,2018)

The process of taaruf, which is conducted through interviews, discussions, and even questions and answers between prospective muallaf at Pesantren An-Naba Center, will provide essential information to gain a bigger picture of prospective muallaf profile and motives. Prospective muallaf gained advantages from taaruf process. They know and understand the risks that they will experience once they convert to Islam. Therefore, this taaruf process or introduction stage to Islamic religion conversion can be considered a preliminary selection to convince prospective muallaf at Pesantren An-Naba Center. If they passed this process, they are welcomed to join a further stage studying Islamic religion more deeply. They 
are expected to be steadfast, confident, and devoted to studying the Islamic religion. There are no words of regret in the future after they embraced and converted to the Islamic religion.

2. Islamic Religious Learning process at Pesantren An-Naba

According to an interview with Pesantren An-Naba's staff, prospective muallaf can proceed to the second process after they accomplished taaruf process. Prospective muallaf should accomplish the first process of taaruf before they could enroll as students at Pesantren An-Naba. Prospective students at Pesantren An-Naba were given a registration form or biodata as prospective Muslim students who will make their shabada at the mosque of Pesantren An-Naba Center. In filling out the form, prospective muallaf describes the information required by Pesantren An-Naba official to write the certificate. The certificate will depend on the information given by the prospective muallaf. They were also asked to sign a statement that they want to study Islam and embrace Islam in a conscious, healthy state of mind and body, without any coercion or pressure from anyone and any party (Ali, personal communication, September 30, 2018).

Based on the explanation from the staff of Pesantren An-Naba, the administrative process should be completed by prospective muallaf. If it is not completed or the prospective students do not sign the certificate, the prospective muallaf could not perform the shahada process. If they accomplish the previous process, they can proclaim shahada. This process was witnessed by all the asatidz, as well as other students who had already embraced Islam and settled or became students at Pesantren An-Naba.

There is another process to follow by muallaf after reading shahada. Prospective students then follow the Islamic religious learning package. They will foster the basics or foundation of Islam, which is carried out at Pesantren An-Naba. This process is programmed by the supervisors, administrators, and Asatidz, at Pesantren An-Naba. Next, they must learn and master the twelve basic Islamic religious education materials in twenty-two meetings and within approximately five months. After they participated in learning activities and fostering the basic religion of Islam, they could take the evaluation process. If they pass the learning evaluation process, they were given a certificate of accomplishment and a certificate explaining Islamic religious conversion. Muallaf at Pesantren An-Naba receives the legal certificate. The certificate can prove that the person who possesses the certificate has converted to Islam. When they have a problem in their family concerning their faith, they can use their certificate to show their Islamic religious conversion party (Ali, personal communication, September 30, 2018).

The Islamic religious conversion certificate also serves other functions for Pesantren An-Naba. It is to facilitate communication and friendship between the institution and muallaf. Pesantren can monitor their comprehension of Islamic religious learning. The administrators also invite muallaf, the Trustees at Pesantren An-Naba, to participate in several religious, social, and educational activities at Pesantren An-Naba. This process is intended to nurture prospective students at Pesantren An-Naba, enhance their understanding of Islamic religious learning, and mingle with the other students at Pesantren An-Naba.

3. Islamic Learning Materials in the Islamic Boarding School An-Naba Center

Pesantren An-Naba has prepared and managed learning material for muallaf. According to an interview with the staff, it can be concluded that the basic learning package of Islamic religion at the Islamic Boarding School of the An-Naba Center had been compiled and formulated by administrators, coaches, and Asatid\%. This is intended to facilitate the stages of learning for muallaf to comprehend Islamic religious learning. Besides, it also facilitates muallaf to learn more effortless to understand the teachings of Islam. The learning material is designed from the basic to advanced Islamic religious learning. This scheme of learning can guarantee the uniformity of muallaf initial understanding of Islamic religious learning. For 
each prospective Muslim student converts to religion Islam. This scheme can be seen in the table 3 .

Tabel 3. Basics of Islamic Religious Learning

\begin{tabular}{|c|c|c|c|c|}
\hline 1 & \multirow{5}{*}{ Theology } & Meaning of Syahadatain & $1 \times 45$ Minutes & \\
\hline 2 & & Knowing the rukun of Islam & $3 \times 45$ Minutes & \\
\hline 3 & & The meaning of Taubid & $1 \times 45$ Minutes & \\
\hline 4 & & Arkanuddin & $1 \times 45$ Minutes & \\
\hline 5 & & Syirik & $\begin{array}{l}1 \times 45 \text { Minutes } \\
7 \times 45 \text { Minutes }\end{array}$ & 315 \\
\hline 1 & \multirow{6}{*}{ Figh } & Thabarah & $1 \times 45$ Minutes & \\
\hline 2 & & Shalat mafrudhoh & $2 \times 45$ Minutes & \\
\hline 3 & & Shalat almasnunah & $1 \times 45$ Minutes & \\
\hline 4 & & Shaum & $1 \mathrm{x} 45$ Minutes & \\
\hline \multirow[t]{2}{*}{5} & & Muamalab & $1 \times 45$ Minutes & \\
\hline & & Halal and haram & $\begin{array}{l}1 \times 45 \text { Minutes } \\
7 \times 45 \text { Minutes }\end{array}$ & 315 \\
\hline \multirow[t]{2}{*}{1} & Al-Quran & Iqra'/Quran & $6 \times 45$ Minutes & 270 \\
\hline & & Total & 24 hours & 900 minutes \\
\hline
\end{tabular}

According to the staff of Pesantren An-Naba, learning Islam at Pesantren An-Naba for muallaf was divided and adjusted to the time of the students' readiness. This decision is made because the students are divided into several classes and have varying school ages. Some belong to elementary schools, and others belong to junior and senior high schools. Ustadz Ali stated that at pesantren An-Naba: "related to this flexible schedule, this is one of the inhibiting factors in the process of Islamic religious learning for students. The principal, coaches, and management hope to seek solutions for muallaf need by always being ready whenever they want to explore and learn Islam" (Ali, personal communication, September 30, 2018).

4. The method of Islamic Religious Learning Methods for muallaf at Pesantren An-Naba

Based on the observation, this study found data concerning the method of Islamic religious learning at Pesantren An-Naba. To deliver the material of Islamic religious learning, Pesantren An-Naba has several methods to apply. Two methods were frequently used, that is the method of discussion and question and answer. They were applied in teaching and learning activities at Pesantren An-Naba to explore the extent of the students' knowledge and insights. They also allowed students to express and communicate their problems to receive insight and suggestions from others.

Based on an interview with the teacher at pesantren An-Naba, there are some explanations for using the methods to deliver Islamic religious learning. The discussion method, question, and answer, and other methods were deliberately applied at Pesantren AnNaba to have more chances to understand the Islamic learning material. The more they are used to various Islamic learning material methods, the better their understanding of Islam religion. (Ali, personal communication, September 30, 2018).

Pesantren An-Naba also applied another method to deliver Islamic religious learning for muallaf. Based on the observation, this study found that pesantren An-Naba for students to participate in a learning session every Friday after the Ashar Prayer. This session discusses various Islamic religious learning themes such as figh, taubid, worship, and morals. This study was carried out to broaden students' insight at pesantren An-Naba. This method is expected to deliver Islamic religious learning as well as to strengthen their faith further. In the afternoon lecture, pesantren An-Naba also invited the da'i (preacher), who were experts in their fields, to teach the students. The Friday prayers often raise the theme of Islamic religious learning currently being discussed in their class. 
Pesantren An-Naba also applied other methods to deliver Islamic religious learning. Based on the observation, this study found that Pesantren An-Naba provided the students the freedom to mingle with pesantren's society. With the society around pesantren, students were allowed to follow the study agenda in society, participate in social activities, participate in the youth organization's activities, and various sports activities involving residents. This method aimed to build their proper insight into their Islamic religious learning correlated to their religion and social life.

In studying Quran, Pesantren An-Naba applied Al-Bana method to teach muallaf students. Based on the observation, this study found that Al-bana method was applied to improve students' ability to read and write Quran. This method requires teachers and students to use cassettes or Compact Discs as a first step to learns from listening. Next stage, the students will learn to read through a Compact Disc. Another method of learning to read and write Qur'an is Iqra Method. For those students who start learning to read Qur'an, this method combines eight ways or teaching material, namely: 1) structural analytic (introducing bijaiyab letters with synthetic words that are easy to remember); 2) kinesthetic (memorizing by writing again); 3) examination (testing of what has been learned); 4) transliteration (learning how to read/pronounce Qur'an in Indonesian); 5) interactive (using Video Compact Disc media in teaching); 6) systematic (featuring structured material); 7) illustration guide (making learning more dynamic and directed); 8) color coding (making it easy to learn recitation with color codes as a method to distinguish tajwid or reading Qur'an rules). Pesantren An-Naba tried its best to carry out Islamic religious learning programs, especially Quran, with ease. This program was intended not only for muallaf students but also for anyone who wanted to learn to read and write Qur'an. In detail, an essential program consisted of 14 meetings. For tabsin program, there were eight meetings to accomplish the program.

5. The Media of Islamic Religious Learning for muallaf at Pesantren An-Naba

There are several media used to deliver Islamic religious learning at Pesantren An-Naba. Based on an interview with the teacher, this study concluded several learning media. The media included tools needed for discussions, whiteboard aids, LCD projectors, chapters of books, and other relevant accessories. Also, the administrators and the asatidz deployed digital media to teach muallaf students Islamic religious learning. They used social media applications such as WhatsApp, Facebook, Twitter, and the website. This type of media was deployed to provide broader access for busy students with their profession and work. Those media enabled students to access Islamic religious learning to learn Islam and add insight into their knowledge (Ali, personal communication, September 30, 2018).

There are several types of programs that Pesantren An-Naba managed to teach muallaf Islamic religious learning in terms of habit formation. The types of habit formation can be seen in the table 4.

Table 4. Forms of Islamic Religious Learning for muallaf at Pesantren An-Naba

\begin{tabular}{|c|c|c|}
\hline No. & $\begin{array}{l}\text { The Implementation of Islamic } \\
\text { religious Learning }\end{array}$ & $\begin{array}{c}\text { Forms of Activities for implementing Islamic } \\
\text { religious Learning }\end{array}$ \\
\hline \multirow{6}{*}{1} & \multirow{6}{*}{$\begin{array}{l}\text { Islamic Religious learning in form of } \\
\text { habituation program }\end{array}$} & a. Greetings or salam \\
\hline & & b. Implementation of learning \\
\hline & & c. Learning to recite the Qur'an and Iqro' \\
\hline & & d. Praying five times a day \\
\hline & & e. Paying infaq and shadaqob \\
\hline & & f. Fasting \\
\hline 2 & Spontaneous habit & a. Infaq and sodaqoh \\
\hline \multirow{3}{*}{3} & \multirow{3}{*}{ Conditioned habituation } & a. exhibiting good morality \\
\hline & & b. Maintaining cleanliness \\
\hline & & c. Maintaining association \\
\hline
\end{tabular}


Pesantren An-Naba provides Islamic Religious learning for muallaf, and it offers a variety of methods and media for Islamic religious learning. It sets the objectives of Islamic religious learning, which are oriented towards the introduction of Islam through the strengthening of muallaf faith, da'wah, and the Qur'an recitation. The material of Islamic religious learning consisted of Islamic knowledge and self-development. The method used is a combination of the methods which is implemented in schools and pesantren. Pesantren AnNaba applied formal institutions by using the school method. On the other hand, non-formal learning was applied through pesantren. The evaluation of Islamic religious learning was carried out regularly; daily, weekly, and monthly.

In the context of religious conversion, when a person has officially experienced a new nuance in belief, he is required to be able to know the values of a new religious system, to behave according to the new system, to be able to adjust and carry out activities according to the new religion. In pesantren for muallaf, the religious conversion will be supported to achieve a person's life which is adjusted to Islamas their new religious identity (Abdillah \& Sjafei, 2019). When a person is converted to Islam, he or she learns to adapt to many things about the new religious system. In pesantren muallaf, they are taught to familiarize with the islamic norms and habits. They can try to avoid their previous habits which are not in accordance with Islam such as pork, abstinence from drinking alcohol, prostitution, lying, and gambling (Emang, 2014).

A number of muallaf admitted that before their religious conversion experience, they were confused about finding people or institutions that could help them answer religious problems. They have problems in carrying out Islamic teachings, especially the pillars of Islam. The problems include feeling lazy to perform praying and fasting Ramadan, lacking awareness of converts, feeling doubt in carrying out obligations, taking time to carry out their obligations, and looking for conformity in deepening Islamic teachings (Supriadi, 2018).

There are some implications for students at Pesantren An-Naba who participated in Islamic religious learning. They include: (1) nurturing the character of the students; migrating from negative to positive in all dimensions of life, (2) nurturing an attitude of militancy in implementing Islamic teachings; forming the habit of istiqamah, (3) memorizing the Qur'an (4) loving the Qur'an (5) being a reliable preacher. The students can achieve those conditions if they follow the program of Islamic religious learning at Pesantren An-Naba (Shidiq \& Hidayatus, 2018).

\section{CONCLUSION}

This study investigated Islamic religious learning for muallaf at Pesantren An-Naba relating to the objectives of optimization and implementation. Islamic religious learning objectives include improving learning quality, having an ideal Muslim personality, having morality, and achieving good Muslim personalities. Pesantren An-Naba optimized Islamic religious learning for muallaf through several efforts. The design of Islamic religious learning programs in the muallaf community consists of coaching programs such as providing basics of aqidah Islamiyah through systematic studies, comparative religion basics, providing sermon training, or public lectures. It also featured educational programs, including organizing non-formal education programs with Islamic Boarding School, aspiring to hold formal education from the elementary/MI levels to universities for the muallaf. The last is the development program, consisting of memorizing the Qur'an and its interpretation, memorizing the badith and surah, mastering Arabic, mastering English, mastering computers, and developing vocational education. Islamic religious learning implementation covered several aspects, such as taaruf, after muallaf accomplished this process, they proceed with Islamic religious learning implementation. This process allowed muallaf students at Pesantren An-Naba to participate in 
Islamic religious learning with material that has been designed by pesantren. They also experience several methods of Islamic religious learning. They were also exposed to the media, both conventional and digital, to comprehend Islamic religious learning at pesantren.

\section{BIBLIOGRAPHY}

Abdillah, A., \& Sjafei, M. S. (2019). Konversi Agama (Studi Fenomenologi pada Mualaf Tionghoa di Kota Banda Aceh). Jurnal Ilmiah Mahasiswa FISIP Unsyiah, 4(4). Retrieved from http://www.jim.unsyiah.ac.id/FISIP/article/view/12933

Abdullah, S. F., Salim, S., Dahaman, M. A., Hamid, S. A., \& Rahman, M. N. A. (2018). Muallaf Da'wah Activities in kedah: Challenges and Solutions. Journal of Social Sciences Research, Special Issue 6, 1125-1131. https://doi.org/10.32861/jssr.spi6.1125.1131

Boz, T. (2011). Religious Conversion, Models and Paradigms. Epiphany: Journal of Transdisciplinary Studies, 4 (1), 128-145.

Chauhan, N. (2017). Religious Conversion and Freedom of Religion in India: Debates and Dilemmas. ILI Law Review. I, 126-136.

Buxant, C. et al.,. (2009). Contemporary Conversions: Compensatory Needs or Self-Growth Motives?. Research for the Social Scientific Study of Religion, 20, 47-68.

Emang, R. (2014). Konversi Agama dan Strategi Pembinaannya di Kota Makassar (Master's thesis, UIN Alauddin Makasar). Retrieved from http://repositori.uinalauddin.ac.id/id/eprint/700/

Gepu, W., et al., (2018). Religious Conversion towards Hindu Kaharingan to Christianity. International Journal of Linguistics, Literature and Culture. 4 (4), 25-37.

Hadidjah, \& Karman. (2010). Pengantar Studi Islam. Hilliana Press.

Hakim, R. (2013). Pola Pembinaan Mualaf di Kabupaten Sidrap Sulawesi Selatan. Jurnal AlQalam, 19(1). https://doi.org/ttp://dx.doi.org/10.31969/alq.v19i1.150

Hakim, R. (2019). The Improvement of Students' Competence in Islamic Education Programme through Tahsin Al-Quran Activities. Khalifa: Journal of Islamic Education, 3(1), 35-55. http://kjie.ppj.unp.ac.id/index.php/kjie/article/view/21

Hardi, N. M. (2019). Komunikasi Antarbudaya Etnis Tionghoa dan Pribumi di Kota Palembang. Jurnal RASI, 1(1), 73-91.

Harun, S., et. al.,. (2012). Factors That Influences Religious Conversion Among Muslim Splinter Groups In Indonesia. OID A International Journal of Sustainable Development, 05 (08), 11-20.

Hawi, A. (2013). Kompetensi Guru Pendidikan Agama Islam. Rajawali Press.

Hidayati, S. (2014). Problematika Pembinaan Muallaf di Kota Singkawang dan Solusinya melalui Program Konseling Komprehensif. Jurnal Dakwah, XV(1), 111-136. https://doi.org/10.14421/jd.2014.15106

Isbah, M. F. (2020). Pesantren in the Changing Indonesian Context: History and Current Developments. Qudus International Journal of Islamic Studies, 8(1), 65-106. https://doi.org /10.21043/QIJIS.V8I1.5629

James, W. (1967). The V arieties of Religious Experience. The Macmillan Company.

Kilbourne, B. \& James T. R. (1989). Paradigm Conflict, Types of Conversion, and Conversion Theories Sociology of Religion, 50 (1), 1-21. https://doi.org/ 10.2307/3710915.

Kawangit, M. R., Don, A. G., \& Mohamad, A. D. (2012). Dakwah kepada Golongan Muallaf Orang Asli di Kelantan. Al-Hikmah: Joumal of Islamic Dakwah, 4(4), 87-105. http://spaj.ukm.my/jalhikmah/index.php/jalhikmah/article/view/21

Kurnia, R., \& Sani, K. (2018). Penanaman Nilai-nilai Agama Islam di Kalangan Keluarga Muallaf. FITRA: Jurnal Pendidiken Islam, 4(1), 39-49. 
Mahfud, C. (2018). Chinese Muslim Community Develpomenr in Contemporary Indonesia: Experiences of Piti in East Java. Studia Islamika, 25(3), 471-502. http://doi:10.15408/sdi.v25i3.6755

Maraghi, A. M. (2000). Tafsir Al-Maraghi. Beirut: Dar al-Fikr.

McGuire, M. B. (2002). Religion The Social Context (5th ed.). Wadsworth Pub. Co.

Muljana, Y. (2011). Dampak Pembinaan dan Pendampingan Mualaf terbadap Perilaku Keagamaan Mualaf di Yayasan Masjid Al-Falah Surabaya (Bachelor thesis, IAIN Syekh Nurjati Cirebon. Retrieved from http://repository.syekhnurjati.ac.id/2519/

Noviza, N. (2015). Penggunaan Bibliotherapy dalam Membantu Penyesuaian Diri pada Mualaf Tionghoa Masjid Al-Islam Muhammad Cheng Ho Palembang. Intizar: Jurnal Kajian Keislaman dan Kemasyarakatan, 21(2), 185-200. http://jurnal.radenfatah.ac.id /index.php/intizar/article/view/306.

Pohl, F. (2006). Islamic Education and Civil Society: Reflections on the Pesantren Tradition in Contemporary Indonesia. Comparative Education Review, 50(3), 389-409. https://doi.org/10.1086/503882

Rahman, A., Warsah, I., \& Murfi, A. (2019). Islamic Education System in Singapore: Current Issues and Challenges. Jurnal Pendidikan Islam, 8(2), 197-222. https://doi.org /10.14421/jpi.2019.82.197-222

Ramayulis. (2009). Psikologi Agama. Jakarta: Kalam Mulia.

Ramayulis. (2015). Ilmu Pendidikan Islam. Jakarta: Kalam Mulia.

Widodo, R. I. (2017). Retrieved from (http://khazanah. republika.co.id/berita/duniaislam/islam-Nusantara/17/02/01/okpetz394-lima-tahun-terakhirada-10-ribu-orangmasuk-islam).

Shidiq, S., \& Hidayatus, S. (2018). Model Pendidikan Muallaf (Studi Kasus: Pesantren Pembinaan Muallaf Yayasan An-Naba Center Indonesia). Penamas: Jurnal Penelitian Keislaman dan Kemasyarakatan, 31(1), 83-106. https://doi.org/10.31330/penamas. v31i1.227.

Sugiyono. (2014). Memahami Penelitian Kualitatif. Alfabeta.

Supriadi, S. (2018). Problematika Muallaf dalam Melaksanakan Ajaran Agama Islam di Desa Tumbang Runen Kecamatan Kamipang Kabupaten Katingan. Jurnal Hadratul Madaniyah, 5(1), 41-44. https://doi.org/10.33084/jhm.v5i1.162

Tumanggor, R.O. (2016). The Conversion of Religion in Psychological Perspective. Asean Conference 2nd Psychology \& Humanity. 836-844.

Umam, K. M. (2014). Pengalaman Konversi Agama pada Muallaf Tionghoa. Character: Jurnal Penelitian Psikologi, 2(3). Retrived from https://jurnalmahasiswa.unesa.ac.id /index.php/character /article/view/10997

Wekke, I. S., \& Hamid, S. (2013). Technology on language teaching and learning: A research on Indonesian Pesantren. Procedia-Social and Behavioral Sciences, 83, 585-589. https://doi.org /10.1016/j.sbspro.2013.06.111

Zinnbauer, B. J. \& Kenneth I. P. (2015). Spiritual Conversion: A Study of Religious Change Among College Students, Journal for the Scientific Study of Religion, 37 (1), 161-180.

Yudha, A. E. P. \& E. Setiyowati. (2016). Mualaf Center Design as an Implementation of Psychological and Economical Effect for Mualaf in Malaysia. Journal of Islamic Architecture, 4(1), 37-43. https://doi.org/10.18860/jia.v4i1.3466 